\title{
THE HUMAN REALM PERCEPTION IN SALMAN RUSHDIE'S NOVEL “TWO YEARS, EIGHT MONTHS AND TWENTY-EIGHT NIGHTS"
}

\section{Tetiana Konovalenko}

\section{INTRODUCTION}

Salman Rushdie has always managed to astonish and to enchant his readers. Creative work according to the canons of magical realism gives the author the opportunities to invite his readers, at first sight, to the usual people's world, which otherwise appears to be characterized by supernatural features, inhabited with usual and unusual creatures, in which next to the ordinary life, absolutely supernatural events are happening. The occurrence of magic phenomenon or the appearances of supernatural creatures and even worlds in various literary works have their place at different stages of events development. In the novel "Two Years, Eight Months and Twenty-Eight Nights", since the first its line, it becomes clear that the story will be told about jinns and their nature, the devil is mentioned there as well. Further the author compares jinns and people, points at certain similar and different features. Besides, since the very beginning, Rushdie questions the future of the human realm depending on the triumph of the good or the evil: "...we have lived another thousand years since those days, but we are all forever changed by that time. Whether for better or for worse, that is for our future to decide" $"$.

It should be mentioned that there is a feature common for all Rushdie's literary works; it is the close link of the depicted in the novel events to the human history as well as the condemnation of the universal human drawbacks and sins.

The novel by Salman Rushdie "Two Years, Eight Months and Twenty-Eight Nights" dives the reader into the whirligig of events so that then to throw him or her out 'rather worn, bewildered and wholly happy

1 Rushdie, Salman (2015) Two Years Eight Months and Twenty-Eight Nights.New York: Random House. 
on the last page,2 . The fabric of the novel is woven through with the deep philosophic ideas such as the reason for being or the power of love.

This is the fairy-tale for adults and it runs about the war of jinns and people. The war is condemned as the phenomenon threatening the existence of the whole world and making the humanity lose all elements of humaneness. The tone of the narration is changing all the time: once it sounds as the motives and manner of eastern fairy-tales, especially closely to "The Thousand Nights and One Night", then the reader finds himself or herself on the pages of History course-book with bare facts on the events and attendant circumstances.

\section{Global Issues of the Human World Revealed}

The author's manner of writing in the genre of magic realism helps him to reveal the global problems of the human world and to strengthen the depiction colours he uses fairy-tale. Michiko Kakutani pointed that "magic realism - which combines heightened language with elements of the surreal - has tended to flourish in troubled areas of the world, or that many of its practitioners have sought to describe calamitous events that exceed the grasp of normal description". He calls it "a mirror of a reality in which the fantastic is frequently part of everyday life - a reality in which military death squads have effectively turned the word "disappear" into a transitive verb". The researcher emphasizes Rushdie's talent in using "the hallucinatory devices of magic realism to try to capture, metaphorically, the sweep and chaos of contemporary reality, its resemblance to a dream or nightmare" and maintaining "that the writer has a responsibility to tackle the larger issues of the day"3.

The versatile talent of Rushdie is in both his manner of writing and the ability to concentrate on the most urgent issues of the mankind. Rusdie's author's style in the novel "Two Years, Eight Months and Twenty-Eight Nights" amazes with its multilayer structure, as the story runs about itself and contains several stories at the same time. The readers from time to time find references or implications to paintings, films, other

${ }^{2}$ Yusefovich, Galyna (2016)Yest li zhizn posle non-fiction? Da! S romanami Salmana Rushdie i Davida Mitchella [Is there a life after Non-fiction? Yes! With novels by Salman Rushdie and David Mitchell]. Meduza [Jellyfish] (electronic journal). 10 Dec. Retrieved from: https://meduza.io/feature/2016/12/10/est-li-zhiznposle-non-fiction. (accessed 24 Dec. 2019).

3 Kakutani, Michiko (2018). Critic's Notebook; Telling Truth Through Fantasy: Rushdie's Magic Realism. New York Times 
literary or scientific works or characters or their authors (Voltaire's Dr. Pangloss, Aladdin's Lamp, Clark Kent, "Ghost Busters", Carroll's "Alice in Wonderland", Gogol's "Nose", Goya's Saturn, Fairy Queen Morgan and Wizard Merlin, Sinatra, Dearg-Due, Vlad Dracula, Mickey Mouse, Gandalf Gray, Rene Magritte's "Golconda", Homer, Isaac Asimov's "Foundation", Harry Potter and many others) as the author arranges for them to meet the characters of those books or remember those art and science representatives. Besides the literary intertextuality, the novel is characterized with historical relevance. The writer equates his artistic depiction of jinns' and people's war with the real wars in human history. He mentions even the Crimean annexation and ATO in Ukraine, as it goes: "crazed paramilitary jinn parasites in charge of tanks in Eastern Europe, shooting passenger aircraft out of the sky" 4 . In general, the writer shows the contemporary period of history as the worst of all, that is as the end of the world. The novel begins with the quotation by Francisco de Goya: "Fantasy abandoned by reason produces impossible monsters: united with her, she is the mother of the arts and the origin of their marvels." Though the second part of it emphasizes the condition for the existence of the real art, the author draws readers' attention to its first part, transforming it and writing it separately: "The sleep of reason brings forth monsters", warning the mankind about the loss of the control over such phenomena as violence, cruelty, terrorism, war.

The novel has deep philosophic content. The background story is devoted to philosophy as well, as it is about two philosophers Ibn Rushd and Ghazali, who have been arguing on the basic philosophy categories for a thousand years. It has been stated in literary critics before that "the polarity of characters is peculiar of most magic realist novels and chimeric prose" $"$. Ghazali is depicted as a negative character, extremely vain and lofty. We cannot say that Ibn Rushd is shown as an absolutely positive character, because he is just a common person having the drawbacks of common people. But his philosophy is deeply humanistic. On the existence of God he says that He is inexpressible, is beyond the borders of people's understanding. His wife Dunia responds to this his statement with a paradox: "Suppose I suppose that God may not exist. Suppose you make me suppose that 'reason,' 'logic' and 'science' possess

4 Rushdie, Salman (2015) Two Years Eight Months and Twenty-Eight Nights.New York: Random House.

${ }^{5}$ Konovalenko, T.V. (2017) Typology of Characters in Magical Realism and Chimeric Prose. Literary Imagination. Issue 3 (2), (November), Volume 19, 744-751. 
a magic that makes God unnecessary. Can one even suppose that it would be possible to suppose such a thing?" ". The main work by Ibn Rushd was 'The Incoherence of the Incoherence', in which he tried to "reconcile the words "reason," "logic" and "science" with the words "God," "faith" and "Qur'an," and he had not succeeded", and his book was set on fire as at that moment "that was what God decided"

The author contrastively compares histories of both jinns' and people' worlds. The existence of the jinns' world is languid, unchanging and dull. People's world is vice versa shown as the realm of constant changes, endless metamorphosis that was the cause of jinns intrusion into this dynamic world. Since the very beginning of the novel we see jinnia Dunia settle in the people's world, devote her life to philosopher Ibn Rushd, bear a great many of his children, though not being his lawful wife. And when he left her and she came back to her jinns' world, "the voyagers from the world of the jinn to ours became fewer in number, ... and the slits in the world became overgrown by the unimaginative weeds of convention and the thornbushes of the dully material"". Rushdie remarks that the mankind defense from the supernatural with their practicality and following their traditions. The situation cannot stay the same all the time, so a little bit later the real begin to interweave with the supernatural.

In the third millennium the bored jinns make up their minds to destroy the Earth and its population. On the one hand, the cause is their boredom and having nothing to do. On the other hand, this is caused by Islamic theologist Ghazali's making free the jinn and jinn's realizing the wish of Ghazali's soul a great deal of time after his death: to frighten the mankind so much that they would gather their wits and returned to the religion. After that the plot is developed according to Rushdie's usual manner of catching action spiced with good humour. Though the aftertaste stays rather anxious.

${ }^{6}$ Rushdie, Salman (2015) Two Years Eight Months and Twenty-Eight Nights. New York: Random House.

7 Rushdie, Salman (2015) Two Years Eight Months and Twenty-Eight Nights.New York: Random House.

8 Rushdie, Salman (2015) Two Years Eight Months and Twenty-Eight Nights.New York: Random House.

9 Rushdie, Salman (2015) Two Years Eight Months and Twenty-Eight Nights.New York: Random House. 
The author describes our world as the mystic illogic of accidental distribution. He writes the chaos and feeling of consistent unprotectedness of the modern mankind into the canon of fairy-tale, though, as we have already remarked, a little bit of its reality seems more and more real within every next chapter. Almost cartooned presentiment of the end of the world, flavoured with jokes and unpredictable realizations of the most fantastic literary plots. However, there is always the danger of chaos having its own algebra. In Rushdie's formula the readers can see thoughtless-fanatic nature of jinns, who are able to be implanted in people and to make them do endless harm.

Chimeric metamorphosis in the novel specify the time and space. The world of jinns, existing like out of the time, is shown in line with the chronological sequence of certain events in the people's world. As for the location of non-human world, it's not all that simple: it exists in the parallel space, from which sometimes the channels to the people's world appear, they are called just "wormholes". The impressive example of such a wormhole is the transfer of Jimmy Kapoor, while which he understands that there the universal laws stop functioning, and "the idea of place ceased to have meaning and was replaced by velocity"10. The author skillfully uses to the best effect the idea of such world's existence and uses the peculiar play on words, as "In that timeless time he had time to perceive that he had entered the transportation system of the world behind the veil of the real, the subcutaneous subway network operating just below the skin of the world he knew, which allowed such beings as the dark jinn and he had no idea who or what else besides to move at FTL speeds - speeds faster than light - around their lawless land for which the word land seemed inappropriate. He had time to hypothesize that for whatever reasonless reason this, the underground railroad of Fairyland, had been sequestered from terra firma for a long time, but had now begun to burst through into the dimension of the actual to wreak miracles or havoc amongst humanbeings" $"$.

But the author also emphasizes on the fact that the static world of the jinns' Fairyland is indeed empty and lacks the sense. This is because "It was human beings who allowed the jinn to express themselves, to create immense wealth for lucky fishermen, to imprison heroes in magic

10 Rushdie, Salman (2015) Two Years Eight Months and Twenty-Eight Nights.New York: Random House.

11 Rushdie, Salman (2015) Two Years Eight Months and Twenty-Eight Nights. New York: Random House. 
webs, to thwart history or enable it, to take sides in wars, between the Kurus and Pandavas, for example, or the Greeks and Trojans, to play Cupid or to make it impossible for a lover ever to reach his beloved, so that she grew old and sad and died alone at her window waiting for him to arrive" ". And the engine of this is that "the human way was doing, the human reality was alteration, human beings were always growing and shriveling and striving and failing and yearning and envying, acquiring and losing and loving and hating, and being, in sum, interesting"13.

Rushdie multilaterally covers the issues of the mankind's existence, their philosophy of life, positive features, drawbacks and sins and all that is on the way of mankind's historical development and can cause either the complete degradation or the complete destruction.

The writer actively works out the philosophic range of issues and usually whirls it into the complicate curl and emphasizes the complexity of those issues as in this extract: "The existence of the jinn posed problems to moral philosophers from the beginning. If men's deeds were motivated by benevolent or malignant sprites, if good and evil were external to Man rather than internal, it became impossible to define what an ethical man might be. Questions of right and wrong action became horribly confusing" "14. Further it runs about moral confusion of the epoch and a lot of work for students of morality. The writer's position is precisely clear, Rushdie ruthlessly exposes hypocrites and canters. To continue this thought, the author offers the theory that "in the old days before the separation of the Two Worlds, they say everyone had his or her personal jinni or jinnia whispering in an ear, encouraging good deeds or bad" "The matter is that people are not to blame for their deeds; the responsibility is on the jinns. The author's open irony emphasizes the hypocrisy of human nature and avoiding their responsibility for their doings. Besides, the issue is covered on the global level, as it goes about wars and conflicts.

12 Rushdie, Salman (2015) Two Years Eight Months and Twenty-Eight Nights. New York: Random House.

13 Rushdie, Salman (2015) Two Years Eight Months and Twenty-Eight Nights. New York: Random House.

14 Rushdie, Salman (2015) Two Years Eight Months and Twenty-Eight Nights. New York: Random House.

15 Rushdie, Salman (2015) Two Years Eight Months and Twenty-Eight Nights.New York: Random House. 
This is the novel-parable on the eternal love and its opposition disability to love, on turning the wisdom into scholasticism, and the belief into fanaticism. The author says: "...that to tell a story about the past is to tell a story about the present. To recount a fantasy, a story of the imaginary, is also a way of recounting a tale about the actual ${ }^{16}$. As it is stated in the novel review, "It is the utopia vice versa: the story written by the name of our far and mysterious predecessors about our epoch deranged time, the time of worders", and in one more it is precisely pointed that "the author so strongly twirled and spinned - and the fiction interweaved with the reality, the past, future and our present with all its problems: bribery, corruption, treachery, murders, ruinous habits...". The author chooses the cruel jinn Zumurrud to say: “... fear and greed, are the tools by which these insects (people) can be controlled with almost comical ease" 17 .

With the precisely professional touches, the writer outlines such problems of society as "American crazy" and the terrible consequences of its degradation: "shooting-kids-at-school or putting-on-a-Joker-mask-andmowing-people-down-in-a-mall or just plain murdering-your-mom-atbreakfast crazy". Here Rushdie explains the cause of all that craziness Second Amendment crazy - usual everyday craziness, starting to be the norm. He speaks of quite real things, realism of our society and our life the Second Amendment to the Constitution of the USA: "A well regulated Militia, being necessary to the security of a free State, the right of the people to keep and bear Arms, shall not be infringed"18. The reader also encounters with other deeds and events which trespass against all the human principles of peaceful existence of the mankind: "knife crazy", "the knockout-game type of crazy that persuaded young black kids it was cool to punch Jews in the face", "drug crazy and politician crazy and Westboro Baptist Church crazy and Trump crazy", "9/11 crazy". To

16 Rushdie, Salman (2015) Two Years Eight Months and Twenty-Eight Nights. New York: Random House.

17 Rushdie, Salman (2015) Two Years Eight Months and Twenty-Eight Nights. New York: Random House.

${ }^{18}$ USA Government (2017) Bearing Arms.Second Amendment. Constitution annotated. 03 Oct. Retrieved from: https://www.congress.gov/content/conan/pdf/ GPO-CONAN-2017-10-3.pdf 
summarize the idea of the mankind going crazy, Rushdie ends this extract with the phrase: "The devil was on the loose",

The deep philosophic wisdom goes through the whole novel. A lot of attention is paid to the analysis of separate actions of the mankind representatives, the regularities of their development, opinions on their lives and the laws of existence, making a mark. Once Mr. Geronimo was written to in a letter by his father: "You'll never amount to anything if you can't stick to anything". But the man remembers his father's words when his legs unstuck in the grounds of La Incoerenza and he is levitating all the time. Ironically he comments: "The old man knew what he was talking about". This is the hint to the all people on the Earth. At the end of the novel, when most people are levitating, i.e. unstuck in the ground, there is "the separation plague" told of and there are the examples of "a noticeable separation of writers from their subjects" in the area of literature, "the separation of causes and effects" in the area of science, "the separation of words and meanings", "the growing separation of the rich from the poor", "a spate of marital separations", end of old friendships. Here the authors uses a kind of zeugma, combining differentlevels things, concrete and abstract, which belong to quite different categories and spheres.

The issues of migration and migrants destinies are revealed in the novel. Thus, Mr. Geronimo thinks on that he "could have roots spreading under every inch of his lost soil, his beloved lost home, that he could have been a part of something, that he could have been himself, walking down the road not taken, living a life in context and not the migrant's hollow journey that had been his fate" 20 . We can see the tragedy of the life of a migrant which is usually more a regularity than a peculiarity. The author demonstrates the wild and cruel laws of living in the people's society: the people who are less protected socially become the targets for people's finding faults with them and making them even unhappier.

Ye.Yu. Chemiakin points that in postcolonial writers' novels there "appears the character belonging to several axiological systems, he

19 Rushdie, Salman (2015) Two Years Eight Months and Twenty-Eight Nights.New York: Random House.

20 Rushdie, Salman (2015) Two Years Eight Months and Twenty-Eight Nights. New York: Random House. 
accepts them and makes himself enriched"21. He analysed the character of a multicultural person in previous novels by Rushdie and other writers, pointing that Rushdie himself was a migrant so he described real emotions, hesitations, sufferings he experienced himself. The scientist points that Rushdie's books are the mixture of fiction and magic with political satire.

So, the appearance of "the machine of the future" in the novel is not accidental. It was thought up by the government of the country to make the people forget about their needs and interests and fully devote themselves to "the machine of the future". Ordinary people become blind and deaf, they do all they are told to do until one day, one of the men was visited by a jinn and was endued with the ability to see what was happening. At that moment the delusion that the machine is building the future was stopped. The people understood that they had been deceived. This story in story represents politicking and populism and reveals the lie, which is brought to the ears of ordinary people by the politicians, who manipulate the society.

The United States President within the described period is shown as a positive, charismatic personality, although not successive in the struggle against jinns and becoming "a president of empty words", "as many of them are, as they all have been, for so very, very long" ${ }^{\text {"2 }}$. Here we can clearly observe the sarcasm on people's losing trust to their presidents and governments.

It also runs on the people's attitude to the information. "In her (Storm Baby) illustrious memory we refuse to allow truth to become "truth", 23. Misinterpretation of information often occurs in mass media, public reports, and to make it worse it becomes the weapon in "the information war" of mankind against themselves. Beyond that the author hints on rewriting pages of mankind's history. The weak politicians are eager to make their mark on the world not by doing something important and necessary, but by rewriting the course-books in History.

21 Chemiakin Ye. Yu. (2011) Obraz multiculturnogo cheloveka v postcolonialnom diskurse [The character of a multicultural man in the postcolonial discourse]. History Annual. P. 25-34.

${ }^{22}$ Rushdie, Salman (2015) Two Years Eight Months and Twenty-Eight Nights.New York: Random House.

23 Rushdie, Salman (2015) Two Years Eight Months and Twenty-Eight Nights. New York: Random House. 
One more issue is arisen by the writer and it is the power of money and it significance in the life of some people. Especially brightly we can see the character of Sanford Bliss through such trifles as: "He (Sanford Bliss) also believed in numerical superstitions, such as the idea that round numbers were unlucky, you never charged ten dollars for a bag of feed, you charged $\$ 9.99$, and you never gave a man a hundred-dollar tip, but always one hundred and one" 24 . The author says that "there wasn't a line of poetry in his head but every dollar figure he'd ever encountered was neatly filed away and readily accessible" 25 . He was a man who "encountered the extraordinarily un-American idea that reality was not something given, not an absolute, but something that men made up, and that values, too, changed according to who was doing the valuing" ${ }^{26}$. And at this moment there appears the continuation of the novel's beginning, represented in Francisco deGoya's quotation: "If zero is the point of sanity at which two plus two always equals four, and one is the fucked-up place where two and two can add up to any damn thing you want them to be"... "then, ..., I'm sorry to tell you that we are currently located somewhere around zero point nine seven three,"27. This is one more hint as for mankind's coming to the critical point of existence.

\section{Rushdie's Means of Making Realism Magic}

The magic of figures is included into the title of the novel "Two Years Eight Months and Twenty-Eight Nights", which is an allusion to "One Thousand and One Nights" and if counted will do the same number of nights. But this number is throughout in the novel while being counted as the same number of days, at first beginning from Ibn Rushd's exile till his return to the court of Caliph Al-Mansur. Nevertheless while this period of time Ibn Rushd was staying with Dunia, whom he was telling his stories at nights, here we can see the hint on one thousand and one nights. Later this number will appear in Mr. Geronimo's life whose wife perished in two years, eight months and twenty-eight days sharp since he

24 Rushdie, Salman (2015) Two Years Eight Months and Twenty-Eight Nights.New York: Random House.

25 Rushdie, Salman (2015) Two Years Eight Months and Twenty-Eight Nights.New York: Random House.

26 Rushdie, Salman (2015) Two Years Eight Months and Twenty-Eight Nights.New York: Random House.

27 Rushdie, Salman (2015) Two Years Eight Months and Twenty-Eight Nights.New York: Random House. 
had begun to work at "La Incoerenza". The author summarises in the following way: "One thousand days and one day. There was no escape from the curse of numbers" 28 .

By the way, the thought of round numbers bringing misfortune goes through the whole novel the red line and the writer for sure does not uses round numbers in it. So, Ibn Rushd awoke after almost one thousand years' lying forgotten in one hundred and one days after the great storm. While arguing with Ghazali he speaks of possibility for religion shriveling away in a thousand and one years and beginning to live in God's truth.

Instead the reader can watch the terrible events happening in one hundred and one nights after the storm when in Jimmy Kapoor's room there appears a jinn who declares that he is the very person to "have danced Time and Space into being" 29 . He also informs on the fact that the portal is "busted open" and "border between what imagineers are imagining and what imaginees are desiring is leaky now" and through the wormholes the jinns will easily come to the human world and will be taking over and it is sure for "hundred and one percent" and he tells Kapoor to "forget about it" 30 .

Describing some supernatural events is accompanied with the author's beliefs on people's attitude to them and generally to real and unreal phenomena, as it runs in the extract where a new character appears - Baby Storm: "...our ancestors realized that many of them had abandoned the laws of realism long ago and felt at home in the more glamorous dimensions of the fantastic" ${ }^{\text {". }}$. At the same time we can see the worldview of Rosa Fast, the honest politician who used Baby Storm's unique abilities for identifying and revealing the lie and hypocrisy, told about the baby: "...We came into office to clean this place up... and chance has given us the human broom with which we can sweep it clean" ${ }^{\prime 3}$. There is a remark on Rosa's being an atheist who believes in miracles. Since the very beginning she understands the Baby Storm's

28 Rushdie, Salman (2015) Two Years Eight Months and Twenty-Eight Nights. New York: Random House.

29 Rushdie, Salman (2015) Two Years Eight Months and Twenty-Eight Nights. New York: Random House.

30 Rushdie, Salman (2015) Two Years Eight Months and Twenty-Eight Nights. New York: Random House.

31 Rushdie, Salman (2015) Two Years Eight Months and Twenty-Eight Nights. New York: Random House.

32 Rushdie, Salman (2015) Two Years Eight Months and Twenty-Eight Nights. New York: Random House. 
mission in the human world, so her ongoing influence on the human history running is called "events of a new kind, events of a type we would have described until very recently as fantastic and improbable" 33 .

The miracles continue to happen to both certain people and the global community. The individual influence can be seen from the small situation when the woman haunted by a rapist turned into a bird or the pervert peeping a celebrity turned into a deer as well as mass metamorphosis when the clothes of all people, present in the city square, disappeared and everything they had with them fell on the ground. Though this everything is presented with both: usual little things (cellphones, pens, keys, credit cards, currency, condoms, women's underwear, guns, knives, the phone numbers of unhappily married women, hip flasks, masks, cologne, photographs of angry daughters, photographs of sullen teenage boys, breath-freshening strips, plastic baggies containing white powder, spliffs, lies, harmonicas, spectacles, bullets) and quite immaterial things such as sexual insecurities, inflatable egos and broken, forgotten hopes ${ }^{34}$. The writer supports the fact that nothing is secret, that shall not be made manifest, described in the Bible. The whole situation reveals not only humans' physical nakedness but also and especially the moral one.

The reader is introduced to the reconceptualisation of reality perception since "things had reached a point at which only science fiction gave us a way of getting a handle on what the formerly real world's nonCGI mundanity seemed incapable of making comprehensible"35. All people who stayed alive after being struck with a lightning were considered to be "persons of interest". The reality interweaves with the fiction, so we can see that calling a jinn with rubbing a lamp becomes quite a usual event but not a wonder. The humanity feels difficult to learn to live in the epoch of wonders. This author's opinion appears to be revealing the humanity's secrets which are much better to remain secret as they demonstrate all sins and drawbacks of the humanity. As Anne Hegerfeldt pointed, marginalization is one of the society issues revealed in magic realist novels: "in order to level the social and cultural hierarchy

33 Rushdie, Salman (2015) Two Years Eight Months and Twenty-Eight Nights. New York: Random House.

34 Rushdie, Salman (2015) Two Years Eight Months and Twenty-Eight Nights. New York: Random House.

35 Rushdie, Salman (2015) Two Years Eight Months and Twenty-Eight Nights. New York: Random House. 
that is colonialism's (patriarchy's/ racism's/chauvinism's/...) legacy, magic realist fiction takes on the perspective of the hitherto oppressed, thereby endorsing their world view as a valid alternative to the dominant outlook $^{36}$. In this genre literary works we can surely observe the authors' sympathy to those who differ from the vast majority and "other marginalized world views are similarly revalued as important contributions which should be taken into account by dominant discourses $^{37}$.

For the brighter picture of the background of endless wonders era, Rushdie uses a number of allusions: "In a Romanian village a woman began laying eggs. In a French town the citizenry began turning into rhinoceroses. Old Irish people took to living in trash cans. A Belgian man looked into a mirror and saw the back of his head reflected in it. A Russian official lost his nose and then saw it walking around St. Petersburg by itself. A narrow cloud sliced across a full moon and a Spanish lady gazing up at it felt a sharp pain as a razor blade cut her eyeball in half and the vitreous humor, the gelatinous matter filling the space between the lens and the retina, flowed out. Ants crawled out of a hole in a man's palm"38. Here the author gives the examples from various world-known literary works to prove that all those wonders were the results of jinns influence.

The poetics of Salman Rushdie's novel under consideration proves to be an extraordinary part of author's individual style. Sometimes it is difficult to define what stylistic device or figure has been used by the author as he involves the richest stylistic potential of a literary language. For instance the depiction of cautious Mr. Geronimo who foresaw that "the fabric of society to tear and disintegrate, who knew that superglue could be used to hold cuts together, who did not trust human nature to build solidly or well" 39 . This extract is fortified with the combination of metaphor and irony which is spread further to tell about Mr. Geronimo’s

${ }^{36}$ Hegerfeldt, Anne (2002) Contentious Contributions: Magic Realism Goes British. Janus Head: Journal of Interdisciplinary Studies in Literature, Continental Philosophy, Phenomenological Psychology, and the Arts, 2002, 5 (2), pp. 62-86.

${ }^{37}$ Hegerfeldt, Anne (2002) Contentious Contributions: Magic Realism Goes British. Janus Head: Journal of Interdisciplinary Studies in Literature, Continental Philosophy, Phenomenological Psychology, and the Arts, 2002, 5 (2), pp. 62-86.

38 Rushdie, Salman (2015) Two Years Eight Months and Twenty-Eight Nights. New York: Random House.

39 Rushdie, Salman (2015) Two Years Eight Months and Twenty-Eight Nights. New York: Random House. 
superstitions and about the fact that in the USA "wicked spirits lived in trees so it was necessary to knock on wood to drive them out, whereas British tree-spirits (he was an admirer of the British countryside) were friendly creatures so one touched wood to get the benefit of their benevolence" ${ }^{, 40}$. It is quite unexpected episode where there is the transfer from Mr. Geronimo's character description to the percertion of his levitation state as leaving God and making the corresponding conclusions as for his further living: "If you walk away from God you should probably try to stay in the good books of Luck"41. The writer uses here the personification, giving the luck the importance of new God who will be able to lead Mr. Geronimo in his further life.

The personification as well as the irony is often used by the author in the novel. These two stylistic devices are rather often used together, for instance: "as if the storm was telling our ancestors, Fuck you, I'm buying the island back" 42 . In this sentence we see the combination of comparison with personification to emphasise that there is nothing happening accidentally, that everything has its causes and consequences.

The author seems to accidentally use the return allusion when tells about creation of a new intellectual group consisting of writers including magic realists. Rushdie's self-irony sounds quite clearly they are mentioned in the same line with idiot movie actors and renegade theologians. General binary opposition "religion - science" acts throughout the whole novel. The question of eternal struggle of these concepts is shown by the author. He depicts the humanity tending to the extremes often not being able to find the golden middle. Thus, we can see that the levitation called by the author "a previously unknown virus: a gravity bug", presents an issue for Mr. Geronimo who tries to explain it and does not know how to do that whether by means of science or religion. He founds the explanation about gravitons in quantum physics, a fundamental science, but this theory appears to be a supposition only which has no confirmation. He continues to study the science and look for the causes of his state and runs across "the language of creation", which cannot be understood by an ordinary person: "isospin doublet, Noether's

40 Rushdie, Salman (2015) Two Years Eight Months and Twenty-Eight Nights. New York: Random House.

41 Rushdie, Salman (2015) Two Years Eight Months and Twenty-Eight Nights. New York: Random House.

42 Rushdie, Salman (2015) Two Years Eight Months and Twenty-Eight Nights. New York: Random House. 
theorem, rotation transformation, up and down quarks, Pauli exclusion principle, topological winding number density, De Rhamcohomology, hedgehog space, disjoint union, spectral asymmetry, Cheshire Cat principle" $" 43$. Rushdie expresses sarcasm on the scientific language which remains beyond people's comprehension. He contradistinguishes science and needs of ordinary people, trying to remind that the science should serve to those people's needs. He mocks at scientists' trying to transfer the science into the extraordinary complex semantic field. After studying the crabbed books Mr. Geronimo realizes that his mind as well as body is getting off the ground.

The humour is present in a number of novel pages. The author's comparisons and similies are especially refined. It can be seen from the fragment where Rushdie tells about the rareness of such cases when jinnia could bear human children and compares it with "That would be as if the breeze were to be impregnated by the hair it ruffled and gave birth to more hair. That would be as if a story mated with its reader to produce another reader" ${ }^{34}$. He speaks of a unique ability of Dunia to bear a great many of Ibn Rushd's offsprings. Some other quite unusual comparisons make a reader smile: "had she produced offspring the way Henry Ford learned to produce motor cars, the way Georges Simenon wrote novels, which is to say, like a factory, or industriously" 45 . Later on the jinnia's maternal abilities will help half-humans-half-jinns to save the human world from annihilation. Dunia appealed to her descendants to find jinni within themselves, because it was the only fact which could help them to save the world they were living in.

Description of all supernatural events or things is supplied with author's humoristic comments. In such a way is described a situation when Dunia flied on her magic carpet into another apartment and appeared in front of Blue Yasmeen and said that she preferred not to use them as "their blasted positioning system is always going wrong"46.

43 Rushdie, Salman (2015) Two Years Eight Months and Twenty-Eight Nights. New York: Random House.

44 Rushdie, Salman (2015) Two Years Eight Months and Twenty-Eight Nights. New York: Random House.

45 Rushdie, Salman (2015) Two Years Eight Months and Twenty-Eight Nights. New York: Random House.

${ }^{46}$ Rushdie, Salman (2015) Two Years Eight Months and Twenty-Eight Nights. New York: Random House. 
The author also uses irony in other cases when he reveals his characters' emotions. When Mr. Geronimo, an earthling man, became the victim of a gravitation deviation and tried to touch the ground without effect, Miss Alexandra Bliss Farina "was watching him through groundfloor French windows with tears streaming down her beautiful young face and something else flowing from her eyes that he couldn't make out. It might have been fear or shock. It might even have been desire" ${ }^{\text {. The }}$ author in some way ironically combines practically incompatible emotional states of the Lady Philosopher.

Irony often turns into sarcasm, especially when it runs on the humans' sins in general or on some separate people's ones. The introduction to the story of Mr. Geronimo's appearance in the world is the preface about people easy going away from such important things as honor, morality, good judgment, and truth. Later on the reader learns about the birth of "the illegitimate son of a firebrand Catholic priest" 48 who could not be given his father's surname to follow the decency. Mr. Geronimo is shown as a deeply miserable person who has neither Motherland nor father's care and cheer that emphasise the causes of his being unfortunate. In a sarcastic comparison combined with antithesis it is expressed that the father appeared as alien to him "as Martians or reptiles, but was also as close as blood could make him" 49 . Father Jerry's character features are described rather contradictory: "the neighborhood's leading matchmaker and its benevolent tyrant, a conservative of the right type $", 50$. The use of oxymoron helps the writer to depict this character more concisely and to demonstrate his own attitude to such actors of society ideals. Besides, he shows that it often can be observed that such people have rather happy living, as Father Jerry was so big authority for the people that "nobody made a fuss when he surreptitiously (meaning that everyone knew about it) made a match for himself with a grave-faced stenographer" and became "a little less than perfectly celibate" ${ }^{51}$. Ironical

47 Rushdie, Salman (2015) Two Years Eight Months and Twenty-Eight Nights. New York: Random House.

48 Rushdie, Salman (2015) Two Years Eight Months and Twenty-Eight Nights. New York: Random House.

49 Rushdie, Salman (2015) Two Years Eight Months and Twenty-Eight Nights. New York: Random House.

50 Rushdie, Salman (2015) Two Years Eight Months and Twenty-Eight Nights. New York: Random House.

51 Rushdie, Salman (2015) Two Years Eight Months and Twenty-Eight Nights. New York: Random House. 
remark in brackets characterizes the people surrounding such a "devoted" priest. But fortunately there is no projection of father's character on Mr. Geronimo, there is only cause-and-effect relationship with his worldview.

The author's words about the motto of the whole humankind sound sarcastically: "No good deed goes unpunished"

Casterbriges smile is described with sarcasm as well: "His smile was a thing of menacing, almost feral sweetness, a smile that could bite your head off. His politeness was terrifying" $" 53$.

Mr. Geronimo's character is depicted as a charismatic personality in spite of being unsociable, influencing nobody, having nobody to follow. Nevertheless he is characterized with positive features and fixed on the soil very much. He even often thought of himself "as a plant, perhaps even as one of those man-plants born of sexual congress between a human being and the earth himself; and, consequently, as the gardened rather than the gardener. He placed himself in the soil of time and wondered, godlessly, who might be gardening him. In these imaginings he cast himself always among the rootless plants, the epiphytes and bryophytes, who must lean upon others, being unable to stand alone. So he was, in his own fancy, a sort of moss or lichen or creeping orchid, and the one he leaned upon, the gardener of his nonexistent soul, was Ella Manezes. His loving and much-loved wife" ${ }^{\text {"54 }}$. Later, after his wife's death he considered his gardened plants to contain the spirit of his deceased wife. When he had to cut his hair on his own, he called himself a gardener of his own head. So, we can see that he had a sense of humour. Though he seemed a person otherworldly but he rather realistically considered his possibilities and thought of the Fortune as "that merciless hag" "55.

He felt himself unnatural but hadn't suspected yet that he did not belong to the plants, but to much more supernatural creatures - jinns. His wife Ella noticed that he smelled like smoke, that "in the throes of his passion the edges of his body softened, became blurry, so that her body

52 Rushdie, Salman (2015) Two Years Eight Months and Twenty-Eight Nights. New York: Random House.

53 Rushdie, Salman (2015) Two Years Eight Months and Twenty-Eight Nights. New York: Random House.

54 Rushdie, Salman (2015) Two Years Eight Months and Twenty-Eight Nights. New York: Random House.

55 Rushdie, Salman (2015) Two Years Eight Months and Twenty-Eight Nights. New York: Random House. 
could melt into his" ${ }^{\text {} 56}$. Here the author does not use the metaphor he just writes in the style of magic realism, as Geronimo is the descendant of jinnia Dunia, a representative of Duniazat. When Dunia lived with Ibn Rushd he did not noticed anything strange in her, but when she appeared in front of him in almost a thousand-year period after his death and confessed about her being a jinnia, he remembers that sometimes "she had looked a little smudged at the edges, as if she were drawn in soft charcoal. Or smoke" ${ }^{, 57}$.

It is curious that the writer outlines Mr. Geronimo's fortune similar to his greatgreatgreatmother's fortune and in the same way as jinnia Dunia fell in love with philosopher Ibn Rushd, Geronimo encountered Alexandra Bliss Farina who got to know incoherence and absurdity of the world, began her long inquiry into pessimism, was sure of "the absurdity of human life and the incompatibility of happiness and freedom"58 and revealed an exceptional gift for the acquisition of languages, she knew eighteen languages. She has quite unusual view on the civilization meaning as considers that "after years of mayhem can a measure of stable beauty be achieved" country place to heel, ... one must kill and kill and kill, one must destroy and destroy" ${ }^{\prime 60}$, but she summarizes her phrase on the global level appealing to the whole world. Having the pseudonym El Criticon, Alexandra published her essay "The Worst of All Possible Worlds" grounding the theory "that the rift between the human race and the planet was approaching a tipping point, an ecological crisis that was metamorphosing into an existential one"61. At first, her colleagues laughed at her without any suspicion of changing their opinion soon and considering her to be a prophetess.

56 Rushdie, Salman (2015) Two Years Eight Months and Twenty-Eight Nights. New York: Random House.

57 Rushdie, Salman (2015) Two Years Eight Months and Twenty-Eight Nights. New York: Random House.

58 Rushdie, Salman (2015) Two Years Eight Months and Twenty-Eight Nights. New York: Random House.

59 Rushdie, Salman (2015) Two Years Eight Months and Twenty-Eight Nights. New York: Random House.

60 Rushdie, Salman (2015) Two Years Eight Months and Twenty-Eight Nights. New York: Random House.

61 Rushdie, Salman (2015) Two Years Eight Months and Twenty-Eight Nights. New York: Random House. 
The isolation of the Lady Philosopher from the society is deeper because of her estate La Incoerenza location on the banks of the Hudson, "which at the end of its journey is a "drowned river," its fresh water pushed beneath the incoming salt tides of the sea" ... "On the banks of the drowned river La Incoerenza likewise resisted order" ${ }^{\text {"62 }}$. The author skillfully combines the nature's, real estate's and personality's peculiar protest to follow the widespread principles to show how difficult it is to live in a human world having another nature in comparison with the majority.

The estate manager Oliver Oldcastle causes the reader's interest as well as he is a rather contradictory person "loving the Bible and loathing the Church" ${ }^{\text {"63 }}$. But characterizing him the author uses more stylistic devices beside of antithethis, for example, the following comparison: "Oldcastle ushered Mr. Geronimo into the grounds, looking like God showing Adam into Eden, and charged him with the task of bringing horticultural coherence to the place" ${ }^{94}$. Comparison is followed by a humorous remark about "horticultural coherence" which sounds in accordance with the philosophic context, but does not seem relevant to the gardening.

Here is one more bright example of Giacomo Donizetti, who had conquered many women in many places without loving them, after whispering of some jinns women no longer fell in love with him instead he began to fall in love with all women he saw, so he "had become a beast in the thrall of the monster Love" $"$. Metaphorical depiction of love proves that any extreme emotional expression can do a lot of harm and even destroy a person.

\section{CONCLUSIONS}

Thus, the author reveals a lot of drawbacks and sins of the humankind and while considering people's balancing between the good

62 Rushdie, Salman (2015) Two Years Eight Months and Twenty-Eight Nights. New York: Random House.

63 Rushdie, Salman (2015) Two Years Eight Months and Twenty-Eight Nights. New York: Random House.

64 Rushdie, Salman (2015) Two Years Eight Months and Twenty-Eight Nights. New York: Random House.

65 Rushdie, Salman (2015) Two Years Eight Months and Twenty-Eight Nights. New York: Random House. 
and the bad makes the conclusion on the fact that "the human race falls more naturally towards the dark" $" 66$.

In the novel Salman Rushdie embodies both a procurator and a pleader of the humankind - he tells about the global problems of the jinns' world having copied them from the people's world: "I see its shallowness: its obsession with shiny baubles, its amorality, its widespread contempt for human beings, which I must call by its true name, racism" ${ }^{\prime 67}$. Nevertheless, Rushdie is an optimist and in the end of the novel he speaks of "a peaceful, civilized world, of hard work and respect for the land", of "a world ruled by reason, tolerance, magnanimity, knowledge, and restraint" and of "the victory of our better natures over the darkness within" ${ }^{\text {68 }}$.

\section{SUMMARY}

This article interprets Salman Rushdie's novel "Two Years, Eight Months and Twenty-Eight Nights" and the global issues of human realm depicted in it. Magic realist novel features are studied on the level of meaning and form. Such traits of author's individual style as the novel's multilayer structure, intertextuality, the interaction of human (real) and jinns (fiction) worlds, real historical events and persons described, condemnation of the universal human drawbacks and sins, philosophic worldview, global issues of human existence are specified. The characters of the novel are analysed and linked to the typical representatives of the human realm. Some stylistic peculiarities of the text are emphasized and interpreted. The article addresses the author's attitude to the characters and various processes and phenomena occurring in people's society.

\section{REFERENCES}

1. Chemiakin, Ye. Yu. (2011) Obraz multiculturnogo cheloveka v postcolonialnom diskurse [The character of a multicultural man in the postcolonial discourse]. History Annual. P. 25-34.

2. Hegerfeldt, Anne (2002) Contentious Contributions: Magic Realism Goes British. Janus Head: Journal of Interdisciplinary Studies in

66 Rushdie, Salman (2015) Two Years Eight Months and Twenty-Eight Nights. New York: Random House.

67 Rushdie, Salman (2015) Two Years Eight Months and Twenty-Eight Nights. New York: Random House.

68 Rushdie, Salman (2015) Two Years Eight Months and Twenty-Eight Nights. New York: Random House. 
Literature, Continental Philosophy, Phenomenological Psychology, and the Arts,2002, 5 (2), pp. 62-86.

3. Kakutani, Michiko (2018) Critic's Notebook; Telling Truth Through Fantasy: Rushdie's Magic Realism. New York Times (electronic journal), 24 Feb. Retrieved from: www.nytimes.com (accessed 22 Dec. 2019).

4. Konovalenko, T.V. (2017) Typology of Characters in Magical Realism and Chimeric Prose. Literary Imagination.Issue 3 (2), (November), Volume 19, pp. 744-751.

5. Mendes, Ana Cristina, Wesley, Charlie (2017)_New Directions in Rushdie Studies. The Journal of Commonwealth Literature,September, 52(3), pp. 417-421.

6. Rushdie, Salman (2015) Two Years Eight Months and TwentyEight Nights. New York: Random House. (In English)

7. USA Government (2017) Bearing Arms.Second Amendment. Constitution annotated. 03 Oct. Retrieved from: https:// www.congress.gov/content/conan/pdf/GPO-CONAN-2017-10-3.pdf (accessed 04 Jan. 2020).

8. Yusefovich, Galyna (2016) Yest li zhizn posle non-fiction? Da! S romanami Salmana Rushdie i Davida Mitchella [Is there a life after Non-fiction? Yes! With novels by Salman Rushdie and David Mitchell]. Meduza [Jellyfish] (electronic journal). 10 Dec. Retrieved from: https://meduza.io/feature/2016/12/10/est-li-zhizn-posle-non-fiction (accessed 24 Dec. 2019).

\section{Information about the author:}

Tetiana Konovalenko,

$\mathrm{PhD}$, Associate Professor, Dean of Philological Faculty, Bohdan Khmelnytsky Melitopol State Pedagogical University 20, Hetmanska str., Melitopol, Zaporizhia region, 72312, Ukraine ORCID ID: http://orcid.org/0000-0003-4867-324X 